how often they are actually consulted by working biologists. Prof. Korschelt's work is, as it were, the library edition of the smaller volumes of Dr. May and Dr. Abeloos; as a stimulus to further work, most people will prefer one of the more concise productions.

(4) For reasons which may be adequate, Dr. Newth has translated Prof. Dürken's "Grundriss der Entwicklungsmechanik". As a translation the work is admirable; but it is unfortunate that no revision of the subject matter was possible. The book attempts to cover a very wide field and it will be appreciated by comparatively elementary students. Its main theme deals with the principles of experimental embryology, with which Prof. Dürken is familiar, but to a significant extent the author strays into the field of cell mechanics, where he is by no means a sound guide.

Although they are not without blemish, the four books here discussed form a more than usually significant contribution to the literature of biology.

J. G.

\section{Chemistry of the Sea}

Das chemische Beobachtungsmaterial und seine Gewinnung; Kalziumkarbonat- und Kohlensäuregehalt des Meerwassers. Teil I: Der Bearbeitung des chemischen Materials. Von Dr. Hermann Wattenberg. (Wissenschaftliche Ergebnisse der Deutscher Atlantischen Expedition auf dem Forschungs- und Vermessungsschiff Meteor 1925-1927, herausgegeben im Auftrage der Notgemeinschaft der Deutschen Wissenschaft von A. Defant, Band 8.) Pp. ix $+333+2$ plates +27 charts. (Berlin und Leipzig: Walter de Gruyter und Co., 1933.) 48 gold marks.

$\mathrm{T}$ HIS volume deals with part of the observations made by Dr. Wattenberg, chemist to the expedition, during the three years' voyage of the Meteor in the South Atlantic, and with much subsequent experimental work which was necessary for the full interpretation of these observations.

The first part deals with the methods used on board, the organisation for dealing with the great number of water samples analysed at sea, the equipment in a restricted space, and contains lists of analytical data which were obtained.

The second part of the volume deals in a very complete manner with the calcium carbonate in the sea. Relatively much calcium occurs in seawater, a part of which-the 'excess base'-is held in solution in combination with earbonic acid. The observations made on board are expressed in terms which indicate the proportion of calcium carbonate to total salts in solution. This proportion is least in the upper layers in low latitudes where calcareous plankton organisms, such as Coccolithophores, utilise dissolved calcium to build their skeletons. A minimum is reached at about $100 \mathrm{~m}$. depth. From some $1,000 \mathrm{~m}$. to near the bottom the proportion remained constant. A significant increase was found near the bottom at great depths, suggesting solution from bottom deposits and dead organisms under great water pressure, which by making the water more acid in reaction increases the solubility of calcium carbonate.

The solubility of calcium carbonate was investigated and is shown to depend upon the partial pressure of carbon disxide in situ, the concentration of neutral salts in solution, the temperature and water pressure of these, the partial pressure of dissolved carbon dioxide is itself interrelated to the total dissolved carbon dioxide, the amount of 'excess base', the hydrogen ion concentration, the temperature and water pressure. The presence of a small amount of borate in sea-water also exerts a slight influence on the solubility.

Experiment and an exhaustive treatment of this physico-chemical system has enabled the author to present his observations in the South Atlantic in terms of saturation of the water with calcium carbonate. The upper layers are found to be supersaturated, particularly in low latitudes. Below some 100-500 metres the water is found to be nearly saturated, while in great depths undersaturation occurs in some areas, owing to the influence of pressure. It is of interest in this connexion that bottom deposits from great depths contain least calcium carbonate and that extensive deposits of structureless chalk occur in low latitudes, as off the coast of Florida.

The third part is devoted to hydrogen ion concentration and dissolved carbon dioxide. A series of charts and sections illustrate the $p \mathrm{H}$ and partial pressure of dissolved carbon dioxide in the South Atlantic, while an account of the physical chemistry of the carbon dioxide system in sea-water is given in the text.

The author's researches on calcium carbonate in the sea, and the clear and concise explanations of the theories involved, make this volume a noteworthy addition to the science of oceanography. 